Piśmiennictwo zakonne $w$ dobie staropolskiej, red. Magdalena Kuran, Katarzyna KaczorScheitler i Michał Kuran, przy współpracy Dawida Szymczaka, Łódź 2013.

TOMASZ STOLARCZYK ${ }^{\mathrm{I}}$

Uniwersytet Łódzki

\title{
Biblioteki klasztorne Braci Kaznodziejów w Gidlach, Łęczycy, Łowiczu, Piotrkowie Trybunalskim i w Sieradzu i ich księgozbiory w XVII wieku. Analiza porównawcza
}

Przedmiotem niniejszego opracowania są biblioteki konwentów dominikańskich, leżących na terytorium pierwotnego archidiakonatu łęczyckiego. Jego obszar pokrywał się niemal z prowincją łęczycką i obejmował późniejszą ziemię łęczycką (razem z Kutnem i okręgiem, które przeszły potem pod względem polityczno-administracyjnym do Mazowsza) sieradzką po kasztelanię rudzką, 3 kasztelanie zapilickie: skrzyńską, małogoską i żarnowską oraz niewchodzące do prowincji Rawskie z Łowiczem (pod względem polityczno-administracyjnym było to Mazowsze) ${ }^{2}$. Na przełomie XIII i XIV wieku archidiakonat łęczycki podzielono na archidiakonaty: łęczycki, uniejowski (1301), kurzelowski (1306), a w początku XVI wieku z drugiego, późnośredniowiecznego archidiakonatu łęczyckiego, wydzielono archidiakonat łowicki ${ }^{3}$. Na tym

\footnotetext{
${ }^{1}$ Tomasz Stolarczyk — doktor nauk humanistycznych w zakresie historii. Pracuje w Bibliotece Uniwersytetu Łódzkiego. Przedmiotem jego zainteresowań naukowych jest historia klasztornych bibliotek dominikańskich i ich księgozbiorów w centralnej Polsce w okresie staropolskim oraz dzieje łęczyckiego konwentu Braci Kaznodziejów. Jest autorem książki Szlachta wieluniska od XIV do połowy XVI wieku (Wieluń 2005), współautorem (wraz z H. Jaworowskim) pracy Osiemnastowieczny ratusz $w$ Łęczycy (Łęczyca 2008), we współpracy z D. Gwisem wydał Kopiariusz przywilejów i innych dokumentów konwentu tęczyckiego Zakonu Kaznodziejów 1387-1616 (Łęczyca 2009). Publikował dotąd ponadto w czasopismach: „Mars. Problematyka i Historia Wojskowości. Studia i Materiały”, „Fides. Biuletyn Bibliotek Kościelnych”, „Przegląd Tomistyczny”, „Rocznik Wieluński”, jak też tomach zbiorowych Niebem i sercem okryta. Studia historyczne dedykowane dr Jolancie Malinowskiej (2002), XXX-lecie Łęczyckiego Oddziału Towarzystwa Naukowego Ptockiego. Przesztość dla przyszłości. Rewitalizacja Zabytków Łęczyckiego (2007), Przestrzeń informacyjna książki (2009), Stare inowe w bibliotece (2010), Łęczycka fara. Kościót i parafia św. Andrzeja Apostoła w Łęczycy (2010), Ludzie i ksiązki. Studia i szkice bibliologiczno-biograficzne. Księga pamiątkowa dedykowana Profesor Hannie Tadeusiewicz (2011). ${ }^{2}$ R. Rosin, Rozwó́ polityczno-terytorialny Łęczyckiego, Sieradzkiego $i$ Wieluńskiego (do przełomu XIV i XV w.), „Rocznik Łódzki” (dalej: RŁ), t. 14 (17): 1970, s. 279, 280, 282; S. M. Zajączkowski, O kształtowaniu się granic dawnych ziem tęczyckiej i sieradzkiej do XVI w., „Slavia Antiqua”, t. 18: 1971, s. 135; R. Rosin, Dzieje miasta do końca XVI w. Część Pierwsza, [w:] Eęczyca. Monografia miasta do 1990 roku, red. R. Rosin, Łęczyca 2001, s. 143.

${ }^{3}$ R. Rosin, Dzieje miasta do końca XVI w., s. 104, 144; T. Grabarczyk, A. Kowalska-Pietrzak, T. Nowak, Dzieje miasta do końca XVI wieku, [w:] Eęczyca. Dzieje miasta w średniowieczu i w XX wieku. Suplement do monografii miasta, red. J. Szymczak, Łęczyca-Łódź 2003, s. 92; P. Staniszewski, Terytorium archidiakonatów: tęczyckiego i towickiego w okresie przedrozbiorowym, „Studia Loviciensia”, R. 3: 2001, s. 257-261.
} 
obszarze w XVII wieku znajdowało się 5 klasztorów Braci Kaznodziejów: w Gidlach (archidiakonat uniejowski), Łęczycy (archidiakonat łęczycki), Łowiczu (archidiakonat łowicki), Piotrkowie Trybunalskim (archidiakonat łęczycki), Sieradzu (archidiakonat uniejowski) ${ }^{4}$. Pod względem administracji zakonnej konwenty łęczycki i łowicki należały wówczas do kontraty ${ }^{5}$ mazowieckiej, a Gidle, Piotrków Trybunalski i Sieradz do wielkopolskiej ${ }^{6}$.

Najstarszym spośród nich był klasztor sieradzki pod wezwaniem św. Stanisława Biskupa i Męczennika. Zdaniem Jerzego Kłoczowskiego został on ufundowany w latach trzydziestych XIII wieku (1233 a 1245/6) przez Kazimierza I Konradowica. Natomiast Jacek Wiesiołowski uważa, że powstał przed 1250 roku i mogło to nastąpić dzięki Konradowi Mazowieckiemu. Drugim pod względem starszeństwa był konwent łęczycki pod wezwaniem św. Doroty Panny i Męczennicy i św. Stanisława Biskupa i Męczennika, ufundowany pomiędzy 1275 a 1279 roku przez Władysława Łokietka i Kazimierza II Kazimierzowica. Następnym był klasztor łowicki pod wezwaniem Świętej Trójcy, który powstał w latach 1404-1414, a jego fundatorami byli arcybiskupi gnieźnieńscy: Mikołaj Kurowski i Mikołaj Trąba. Natomiast konwent piotrkowski pod wezwaniem św. Doroty Panny i Męczennicy według tradycji zakonnej i części historyków - J. Wiesiołowskiego i Witolda Glinkowskiego - został założony przez Kazimierza Wielkiego, a nawet Władysława Łokietka. Jednak pierwsze źródłowo potwierdzone dane o tym klasztorze pochodzą dopiero z 1458 roku, a piotrkowskie zgromadzenie pojawia się w źródłach regularnie od 1466 roku. Najmłodszym klasztorem dominikańskim na omawianym terenie był klasztor w Gidlach (pod wezwaniem Wniebowzięcia Najświętszej Maryi Panny) założony w 1615 roku i istniejący do dzisiaj ${ }^{7}$.

\footnotetext{
${ }^{4}$ S. Litak, Atlas Kościoła łacińskiego w Rzeczypospolitej Obojga Narodów w XVIII wieku, Lublin 2006, s. $231,232,233,235,237$.

${ }^{5}$ Jednostka administracyjna w ramach prowincji dominikańskiej, złożona z kilku klasztorów na czele z wikariuszem mianowanym przez prowincjała (Encyklopedia katolicka, t. 9, red. A. Szostek i in., Lublin 2002, kol. 763).

${ }^{6}$ J. Kłoczowski, Dominikanie polscy na Ślasku w XIII-XIV wieku, Lublin 1956, mapa: Polska prowincja dominikańska w pocz. XVI wieku.

${ }^{7}$ Tamże, s. 289, 293, 301, 302 311, 313; M. Rawita-Witanowski, O starym Piotrkowie, „Kronika Piotrkowska”, R. 1: 1910, nr 10 z 7 maja, s. 2; J. Wiesiołowski, Dominikanie w miastach wielkopolskich w okresie średniowiecza, [w:] Studia nad historia dominikanów w Polsce 1222-1972, red. J. Kłoczowski, t. 1, Warszawa 1975, s. 206-208, 212-213, 214; R. Rosin, Dzieje miasta do końca XVI wieku, s. 151; T. Grabarczyk, A. Kowalska-Pietrzak, T. Nowak, dz. cyt., s. 98; R. Rosin, Piotrków Trybunalski w średniowieczu, [w:] 750 lat Piotrkowa Trybunalskiego. Materiaty na sesję naukową, Piotrków Trybunalski 1967, s. 31; Zakony męskie w Polsce w 1772 roku, oprac. L. Bieńkowski, wsp. E. Janicka-Olczakowa, L. Müllerowa, [w:] Zakony meskie w Polsce w 1772 roku. Ordines regulares virorum in Polonia Anno 1772, red. L. Bieńkowski, J. Kłoczowski, Z. Sułowski, Lublin 1992, s. 208; W. Glinkowski, Układ przestrzenny, obwarowania i zabudowania miasta w XVI-XVIII wieku; [w:] Dzieje Piotrkowa Trybunalskiego, red. B. Baranowski, Łódź 1989, s. 65; Z. Kryściak, Klasztory w przestrzeni miejskiej Łowicza do końca XVI wieku, „Roczniki Łowickie", t. 2: 2004, s. 53.
} 
Głównym celem Zakonu Braci Kaznodziejów było i jest głoszenie Słowa Bożego, czyli kaznodziejstwo ${ }^{8}$. Służyć temu miały specjalne studia dominikańskie, dające wykształcenie teologiczne oraz filozoficzne. W każdym klasztorze, już od momentu jego powstania, funkcjonowała szkoła konwentualna'. Według Ireny Szostek, „szkoła każda - aby mogła pełnić funkcje dydaktyczno-wychowawcze, musi posiadać bibliotekę jako bazę naukową i warsztat pracy" ${ }^{10}$. Zgadza się z nią Krystyna Zawadzka, która twierdzi, że „z kształceniem zakonników, a także z pełnieniem przez nich obowiązków kapłańskich (kazania, spowiadanie, odprawianie mszy) wiązały się nierozłącznie książki" ${ }^{\prime 1}$. Kapituła generalna rzymska w 1569 roku nakazała wręcz, aby każdy klasztor miał swoją bibliotekę ${ }^{12}$. Bibliotek klasztornych było tyle, ile było klasztorów ${ }^{13}$.

Ich funkcjonowanie regulowało ustawodawstwo zakonne, począwszy od samej reguły i konstytucji, a skończywszy na kronikach klasztornych i rejestrach wydatków ${ }^{14}$. Najważniejsze przepisy dotyczące książek i bibliotek znajdowały się w De vita regulari Humberta de Romanis, podstawowym podręczniku życia dominikanów (XIII wieku). Trzynasty rozdział, zatytułowany De officio librarii, podzielony był na 4 podrozdziały. W pierwszym, Circa armarium ${ }^{15}$, określono obowiązki bibliotekarza. Miał on dbać o stan zachowania ksiąg, które nie mogły być narażone na wilgoć i pleśń oraz musiały być zabezpieczone przed deszczem. Bibliotekarz musiał w tym celu znaleźć odpowiednie miejsce do ich przechowywania, z dostępem świeżego powietrza. Szafy z książkami musiały mieć odpowiednie oznaczenia, na przykład według fakultetów. Bibliotekarz miał także obowiązek udostępniania książek czytelnikom w określonym czasie, i aby być zawsze w pobliżu, powinien mieć celę na terenie biblioteki albo obok niej. Do obowiązków bibliotekarza należało także prowadzenie księgi zmarłych członków konwentu (liber mortuorum), gdzie zapisywano imię i rok śmierci zakonnika. Drugi podrozdział, Circa libros, mówił o konieczności spisania wszystkich książek. Ich spis miał być przekazywany przez bibliotekarza swojemu następcy. Na każdej książce musiał być umieszczony napis, kto jest aktualnym jej właścicielem. Do obowiązków bibliotekarza

\footnotetext{
${ }^{8}$ F. D. Boespllug, Życie zakonne Braci kaznodziejów, [w:] Dominikanie. Szkice z dziejów zakonu, red. M. A. Babraj, Poznań 1986, s. 36; J. Salij, Duchowość dominikańska, [w:] Dominikanie. Szkice z dziejów zakonu, s. 25.

${ }^{9}$ K. Kaczmarek, Szkoty i studia polskich dominikanów w okresie średniowiecza, Poznań 2005, s. 72; K. Zawadzka, Biblioteki klasztorne dominikanów na Śląsu (1239-1810), „Acta Universitatis Wratislaviensis. Bibliothecalia Wratislaviensia”, t. 5: 1999, s. 18.

${ }^{10}$ I. Szostek, Biblioteka dominikanów lwowskich w świetle katalogu z roku 1776, [w:] Studia nad historia dominikanów w Polsce 1222-1972, t. 2, s. 410.

${ }^{11} \mathrm{~K}$. Zawadzka, Biblioteki klasztorne, s. 18.

${ }^{12}$ R. Świętochowski, Biblioteka OO. Dominikanów w Krakowie, „Archiwa, Biblioteki i Muzea Kościelne” (dalej: ABMK), t. 33: 1976, s. 300; T. Stolarczyk, Biblioteka tęczyckiego konwentu dominikańskiego i jej ksiegozbiór w poczatkach XVII wieku, [w:] Przestrzeń informacyjna książki, red. J. Konieczna, S. KurekKokocińska, H. Tadeusiewicz, Łódź 2009, s. 234.

${ }^{13}$ H. E. Wyczawski, Kościelne zbiory biblioteczne (wiek XVI-XVIII), [w:] Dzieje teologii katolickiej w Polsce, red. M. Rechowicz, t. 2: Od odrodzenia do oświecenia, cz. 2, Lublin 1975, s. 532.

${ }^{14}$ I. Szostek, dz. cyt., s. 412, 414.

${ }^{15}$ Armarium — miejsce przechowywania broni, którą dla dominikanina była książka.
} 
należeć miało także gromadzenie nowych zbiorów, ich selekcja. Dublety i książki mało czytane powinny zostać sprzedane, a za uzyskane pieniądze należało kupić bardziej przydatne dzieła. Co roku lub co dwa lata, należało przeprowadzać w bibliotece skontrum, a uszkodzone książki oddać do konserwacji. Każdą zaginioną pozycję zalecano obowiązkowo odszukać. W trzecim podrozdziale, Circa usum librorum, omówiono sposoby przechowywania książek w bibliotece i kryteria, według których ustawiano na pulpitach najczęściej czytane: Biblię z glosami w całości lub jej części, Biblię bez glos, Sumy, O niedoskonatościach i cnotach, $O$ watpliwościach, konkordacje, interpretacje, dekrety, O rozróżnieniach moralnych, kazania różne o świętach i niedzielach przez cały rok, historie, sentencje, kroniki, pasje, legendy o świętych, Historię kościelną. Biblioteka miała być otwierana o stałych porach. Wypożyczać poza bibliotekę można było tylko za zgodą magistra studentów, a każde wypożyczenie musiało być odnotowane. Zapis anulowano przy zwrocie. Na książkach nie wolno było robić notatek, niszczyć ich, źle się z nimi obchodzić i wypożyczać dalej. Tym, którzy nie zastosowaliby się do tych zasad, przełożony powinien udzielić nagany. Jednak gdyby dogodniej było, żeby książka przechodziła z rąk do rąk, to należało ją zanotować lub wziąć zastaw i pilnować, aby została oddana w określonym terminie. W czwartym podrozdziale, Circa annexa studio, zostały omówione pomoce dla zakonników pragnących się uczyć lub pracować w bibliotece - powinny znajdować się tam inkaust, pióra, kreda, ołówki, linijki, nożyki do ostrzenia piór i tym podobnie. Pergamin otrzymać mogli ci bracia, którzy potrzebowali go do notowania wykładów, dysput i tym podobnie ${ }^{16}$. Zdaniem I. Szostek

przepisy biblioteczne robią wrażenie dobrze osadzonych w konkrecie, przemyślanych, wyraźnie opartych na doświadczeniu. Regulamin udostępniania idzie jak najbardziej na rękę czytelnikom, starając się równocześnie nie dopuścić do niszczenia i rozproszenia zbiorów. Bez żadnych zmian omal, można by go i dzisiaj wywiesić w bibliotekach ${ }^{17}$.

Żadnemu z braci, niezależnie od piastowanej godności, nie wolno było zabierać książek ze wspólnej biblioteki. Tego, kto bez zezwolenia wypożyczył lub w inny sposób wyciągnął książkę z biblioteki, należało skłonić do oddania i pozbawić prawa korzystania z księgozbioru. Opornego zakonnika należało przymusić do zwrotu karą karceru, a nawet ekskomuniki. Zezwolenia na wypożyczenia udzielał przeor po naradzie $\mathrm{z}$ ojcami ${ }^{18}$. Jakub z Korzkwi, biskup płocki, wydał szczegółowe przepisy dotyczące wypożyczania książek do domu; wymagano nawet przysięgi od wypożyczających i odpowiednich gwarancji dotyczących zwrotu książek ${ }^{19}$.

W prowincji polskiej, oprócz wyżej wymienionych przepisów, obowiązywały dodatkowe zasady. Zakonnik mógł dziedziczyć, za zgodą prowincjała, książki po innym

\footnotetext{
${ }^{16}$ Incipiunt instructiones Magistri Humberti De officiis ordinis, [w:] B. Humberti de Romanis quinti Praedicatorum Magistri Generalis Opera De vita regulari, wyd. J. J. Berthier, vol. 2, Casali 1956, s. 263-266;

I. Szostek, dz. cyt., s. 410, 412-413; T. Stolarczyk, dz. cyt., s. 234-235.

${ }^{17}$ I. Szostek, $d z$. cyt., s. 413-414.

${ }^{18}$ Tamże, s. 412.

${ }^{19}$ M. T. Zahajkiewicz, Zarys dziejów i znaczenie bibliotek kościelnych, ABMK, t. 56: 1988, s. 135.
} 
zakonniku. Nie mogły one jednak pochodzić od tegoż prowincjała lub z jakiegoś klasztoru, czyli musiały być własnością zapisującego. W przypadku śmierci któregoś z tych dwóch braci ten, który przeżył, stawał się posiadaczem książek, ale pod warunkiem, że konwent, w którym przebywał ostatnio zmarły, będzie miał swobodny dostęp do nich. Jeżeli jednak obaj już umrą, to książki będą wówczas należeć do klasztoru, w którym przebywał pierwszy ze zmarłych. Dominikanin mógł zapisać swój księgozbiór również swojemu bratu lub bratankowi, a gdy któryś z nich zmarł, wówczas książki wracały do zakonnika. Natomiast jeżeli zmarłby młody profes, to nikt nie mógł odziedziczyć książek, które ten miał po swoich rodzicach lub przyjaciołach ${ }^{20}$.

Książki w bibliotekach konwentualnych pochodziły z darów i zapisów osób spoza zakonu, spadków po zmarłych zakonnikach oraz z zakupów. Bracia, wracający ze studiów zagranicznych, musieli przywozić ze sobą nowości teologiczne. Zalecano również zbieranie od nowicjuszy posiadanych przez nich książek w celu włączenia ich do biblioteki konwentu. W ciągu roku każdy klasztor zobowiązany był wydawać na zakup książek równowartość ubrania zakonników. Należało kupować dzieła autorów „poważnych”, współczesnych, przede wszystkim pisarzy dominikańskich, ale obok nich także starożytnych ${ }^{21}$.

Największy księgozbiór posiadali dominikanie sieradzcy, którzy mieli ok. 400 woluminów. Na drugim miejscu znajdowała się biblioteka w Gidlach z 345 woluminami. $\mathrm{Na}$ trzecim miejscu była biblioteka konwentu łowickiego, która liczyła 294 woluminy. Czwarte miejsce zajęła biblioteka w Piotrkowie Trybunalskim, która posiadała około 215 woluminów. Natomiast w bibliotece łęczyckiej na początku XVII wieku znajdowało się około 100 woluminów ${ }^{22}$. W przypadku Łęczycy, Łowicza, Piotrkowa Trybunalskiego i Sieradza można to stwierdzić na podstawie dwóch łacińskich inwentarzy bibliotecznych wchodzących w skład kopiariuszy akt tychże konwentów, przechowywanych obecnie w Archiwum Polskiej Prowincji Dominikanów w Krakowie. Pierwsze inwentarze tych klasztorów (dalej: inwentarze A) powstały w 1602 roku i zatytuło-

\footnotetext{
${ }^{20}$ Zbiór formuł zakonu dominikańskiego prowincji polskiej z lat 1338-1411, wyd. J. Fijałek, Kraków 1938, nr 300, 318, 341, 342, s. 372, 380, 387.

${ }^{21}$ I. Szostek, dz. cyt., s. 412, 414; J. A. Spież, Dominikanie w kulturze polskiego średniowiecza, „Znak” 1973, nr 223, s. 104; J. A. Kosiński, Biblioteka konwentu dominikanów w Sieradzu na przetomie XVI i XVII w., [w:] Studia nad historia dominikanów w Polsce 1222-1972, t. 2, s. 393.

${ }^{22}$ Archiwum Polskiej Prowincji Dominikańskiej w Krakowie (dalej: APPDK). Copiarium privilegiorum et aliorum documentorum Conventus Lovicensis ab Anno 1600-1644 (dalej: CPDCLv), s. 26-31, 39-41; APPDK. Kopiarz dokumentów dotyczących klasztoru OO. Dominikanów w Piotrkowie 1471-1610 (dalej: KKDPt); APPDK. Copiarium privilegiorum Summorum Pontificum, regum, actum iudicalium et aliorum documentorum conventus Siradiensis Ordinis Praedicatorum spectantia 1377-1692 (dalej: CPCS), s. 173189, 223-229; APPDK. Katalog książek biblioteki klasztoru OO. Dominikanów w Gidlach (dalej: KDG); Copiarium privilegiorum et aliorum documentorum Conventus Lanciciensis Ordinis Praedicatorum 13871616 - Kopiariusz przywilejów i innych dokumentów konwentu tęczyckiego Zakonu Kaznodziejów 13871616, oprac. T. Stolarczyk, wsp. D. Gwis (dalej: CPDCL), Łęczyca 2009, s. 69-73, 78-80; J. A. Kosiński, dz. cyt., s. 394; Z. Łuczak, Dzieje bibliotek w Sieradzu od powstania miasta do końca XX wieku, Sieradz 2007, s. 34; T. Stolarczyk, dz. cyt., s. 236; H. Żerek-Kleszcz podała informację, że w 1646 roku wojewoda kijowski A. Piaseczyński przekazał swoją bibliotekę piotrkowskim dominikanom (H. Żerek-Kleszcz, Życie religijne i kulturalne w XVI-XVIII w., [w:] Dzieje Piotrkowa Trybunalskiego, s. 183).
} 
wane były w Łęczycy, Łowiczu i Piotrkowie Trybunalskim Libri Conventus, a w Sieradzu Cathalogus librorum Bibliothecae Conventus Syradiensis. Drugie inwentarze (dalej: inwentarze B) klasztorów łęczyckiego, łowickiego i piotrkowskiego nie mają podanej daty powstania, ale należy stwierdzić, że pochodzą również z początku XVII wieku i są prawdopodobnie późniejsze od inwentarzy A. Inwentarze te zatytułowane były w Łęczycy Officyna Bibliotecze Conventus Lanciciensis, w Łowiczu Officina Librariae, w Piotrkowie Trybunalskim Index librorum omnium spectantium ad conventum Petricoviensem Ordinis Praedicatorum. Natomiast drugi inwentarz sieradzki, zatytułowany Libri Conventus Siradiensis, pochodzi z lat trzydziestych XVII wieku ${ }^{23}$. Siedemnastowieczny księgozbiór gidelski można odtworzyć zaś dopiero na podstawie inwentarza pochodzącego z początku XX wieku (1903 roku), gdyż miejscowy konwent nie posiadał wcześniejszych ${ }^{24}$.

Inwentarze Braci Kaznodziejów w Łęczycy, Łowiczu, Piotrkowie Trybunalskim i Sieradzu pomijają całkowicie adresy wydawnicze druków, podają czasami nazwisko autora bez jego imienia lub samo imię bez nazwiska bądź też jego imię i nazwisko bez tytułu książki, albo sam tytuł — zawsze skrócony — bez autora. Czasami wymieniano tylko pseudonim pisarza. Inwentarze nie posiadają numeracji przy poszczególnych pozycjach zapisu, jedynie niemal każdy opis zaczyna się od nowego wiersza ${ }^{25}$.

W łęczyckich i łowickich inwentarzach A nie zastosowano żadnego kryterium, wymieniając książki jedną po drugiej (tak też zapewne stały na półkach bibliotecznych) ${ }^{26}$. Natomiast w piotrkowskim inwentarzu A i obu sieradzkich książki podzielono według formatów druków: folio, quarto, octavo, i duodecimo (sedecimo). W szeregowaniu książek w obrębie formatów panowała dowolność: dzieła tego samego autora wymieniano w kilku miejscach ${ }^{27}$.

W inwentarzach B tych klasztorów wygląda to już lepiej, gdyż również dzieła znajdujące się w Łęczycy, Łowiczu i Piotrkowie Trybunalskim podzielone zostały według formatu druku. W tychże inwentarzach wszystkich klasztorów, oprócz gidelskiego, starano się także umieszczać generalnie książki tego samego autora obok siebie, chociaż też nie zawsze, a także starano się umieścić obok siebie dzieła tego samego rodzaju: Bibliae i komentarze do Pisma Świętego, konkordancje, Sumy, Sermones i Contiones oraz Postillae i Homiliae, historie, legendy o świętych, księgi Ojców Kościoła, liturgika, prace z teologii dogmatycznej, moralnej i spekulatywnej, polemiki, słowniki,

\footnotetext{
${ }^{23}$ APPDK. CPDCLv, s. 26-31, 39-41; APPDK. KKDPt; APPDK. CPCS, s. 173-189, 223-229; CPDCL, s. 69-73, 78-80; J. A. Kosiński, dz. cyt., s. 394-395; Z. Łuczak, dz. cyt., s. 34; T. Stolarczyk, dz. cyt., s. 236.

${ }^{24}$ APPDK. KDG.

${ }^{25}$ APPDK. CPDCLv, s. 26-31, 39-41; APPDK. KKDPt; APPDK. CPCS, s. 173-189, 223-229; CPDCL, s. 69-73, 78-80; J. A. Kosiński, dz. cyt., s. 395; Z. Łuczak, dz. cyt., s. 34-35; T. Stolarczyk, dz. cyt., s. 236.

${ }^{26}$ APPDK. CPDCLv, s. 39-41; CPDCL, s. 78-80; T. Stolarczyk, dz. cyt., s. 236.

${ }^{27}$ APPDK. KKDPt,; APPDK. CPCS, s. 173-189, 223-229; J. A. Kosiński, dz. cyt., s. 395; Z. Łuczak, dz. cyt., s. 34-35.
} 
dzieła z filozofii, retoryki, autorzy starożytni ${ }^{28}$. Było to zgodne z instrukcjami przechowywania i ustawiania książek w bibliotece ${ }^{29}$. Oba spisy informują o rękopisach oraz o uszkodzeniach woluminów ${ }^{30}$. W łowickim inwentarzu B wyróżniono ponadto osobno Libri seculares, chociaż wśród nich znajdują się też pisma kościelne, a w piotrkowskim Libri oratorum ${ }^{31}$.

Inwentarz gidelski natomiast podaje pełne adresy wydawnicze, pełne imiona i nazwiska autorów. Podobnie jednak jak w pozostałych inwentarzach nie zastosowano żadnego kryterium, wymieniając książki jedną po drugiej ${ }^{32}$.

Inwentarze różnią się znacznie liczbą zapisanych dzieł. Łęczycki inwentarz A wykazuje istnienie w bibliotece 42 woluminów, inwentarz B notuje ponad 74 woluminy — precyzyjna liczba niemożliwa jest do podania, gdyż nieznana jest dokładna liczba dzieł niektórych autorów. Natomiast łowicki inwentarz A wykazuje istnienie w bibliotece 88 woluminów, zaś inwentarz B notuje już 259 woluminów. W piotrkowskim inwentarzu A odnotowano 85 woluminów, natomiast w inwentarzu B już 143 woluminy. Natomiast sieradzki inwentarz A wymienia 353 woluminy, zaś inwentarz B 414 woluminów. $Z$ zestawienia odpowiadających sobie zapisów w obu inwentarzach wynika, iż inwentarze A zawierają pozycje, które nie weszły do inwentarzy B, późniejszych, mających zatem objąć cały wcześniejszy zasób księgozbioru (na przykład w Sieradzu 102 dzieła ujęte w inwentarzu z 1602 roku nie znalazły się w inwentarzu B, w Łęczycy tych ksiąg było 14$)^{33}$. Analizując oba spisy, można pokusić się chyba o hipotezę, że po pierwszym skontrum zorientowano się, iż w bibliotekach panuje nieporządek. Wskutek tego podjęto decyzję, żeby uporządkować klasztorne księgozbiory. Zrobiono to tak, jak przedstawiają inwentarze B. Trudno jednak stwierdzić jednoznacznie, w jaki sposób powiększyły się zbiory biblioteczne, zaprezentowane w inwentarzach B, w stosunku do zbiorów z inwentarzy A. Możliwe, że te brakujące książki zostały zwrócone przez czytelników - nowicjuszy, zakonników, lektorów — którzy je wypożyczyli wcześniej, albo też nabyto je inną drogą. Jednocześnie nie można precyzyjnie wytłumaczyć, dlaczego brak jest w inwentarzach B woluminów, które odnotowano w inwentarzach A. Prawdopodobnie książi te w chwili ponownego spisywania inwentarzy nie znajdowały się w szafach bibliotecznych, lecz były wypożyczone, a bibliotekarze nie pokusili się o ich ściągnięcie na czas skontrum albo też w bliżej nie wyjaśniony sposób zaginęły ${ }^{34}$.

\footnotetext{
${ }^{28}$ APPDK. CPDCLv, s. 26-31; APPDK. KKDPt; APPDK. CPCS, s. 173-189; CPDCL, s. 69-73;

T. Stolarczyk, dz. cyt., s. 236.

${ }^{29}$ Incipiunt instructiones Magistri Humberti, s. 265; I. Szostek, dz. cyt., s. 413-414; T. Stolarczyk, dz. cyt., s. 235.

${ }^{30}$ APPDK. CPDCLv, s. 26-31, 39-41; APPDK. KKDPt,; APPDK. CPCS, s. 173-189, 223-229;

CPDCL, s. 69-73, 78-80; T. Stolarczyk, dz. cyt., s. 236.

${ }^{31}$ APPDK. CPDCLv, s. 26-31; APPDK. KKDPt.

${ }^{32}$ APPDK. KDG.

33 APPDK. CPDCLv, s. 26-31, 39-41; APPDK. KKDPt; APPDK. CPCS, s. 173-189, 223-229;

CPDCL, s. 69-73, 78-80; J. A. Kosiński, dz. cyt., s. 402; Z. Łuczak, dz. cyt., s. 32; T. Stolarczyk, dz. cyt., s. $236,237$.

${ }^{34}$ T. Stolarczyk, $d z . c y t$. , s. 236-237.
} 
Chcąc dokonać przeglądu zasobów bibliotek dominikańskich pod kątem ich zawartości treściowej, należy zgrupować zapisy w inwentarzach według treści dzieł, posługując się typową dla bibliotek klasztornych klasyfikacją: dzielono wówczas następująco na Biblie i konkordancje, Komentarze do Pisma Świętego, Ojcowie, Doktorzy i apologeci Kościoła, Teologia spekulatywna i dogmatyczna, Teologia moralna, Kaznodziejstwo, Polemiści, Hagiografia, Ascetyka i mistyka, Pasje, Katechetyka, Liturgika, Prawo kościelne i świeckie, Filozofia, Historia kościelna i świecka, Autorzy starożytni, Humaniści, Słowniki i tablice, Varia ${ }^{35}$.

W bibliotece konwentu gidelskiego było tylko 9 dzieł w języku polskim: Arka Testamentu, zamykajaca $w$ sobie kazania niedzielne całego roku Szymona Starowolskiego ${ }^{36}, \mathrm{Ka}$ zania Jana Gaudentego, Gospodyni Nieba i Ziemie, Najświętsza Panna Maria dwudziesta. kazań na Hymn kościelny O Gloriosa Domina etc. po różnych w Krakowie kościołach Jacka Liberiusza $^{37}$, Zywot św. Dominika, Kazania św. Franciszka Salezego biskupa i książecia genewskiego ${ }^{38}$, Przewodnik grzeszników Ludwika z Granady ${ }^{39}$, Rok Niebieski Jana Nadasiego $\mathrm{w}$ thumaczeniu Franciszka Iworskiego ${ }^{40}$ i Reguta św. Augustyna ${ }^{41}$. Zdecydowanie przeważały książki w języku łacińskim i włoskim. Według inwentarza konwent gidelski posiadał w XVII wieku tylko 1 rękopis: Antyfonarz ${ }^{42}$.

W księgozbiorze łęczyckim jedynie 2 książki były w języku polskim: Biblia (bliżej nie określone wydanie) i Kazania Piotra Skargi (tytuł nieustalony). Pozostałe dzieła zostały napisane w języku łacińskim. Według inwentarza A w bibliotece konwentu dominikańskiego znajdowały się tylko 2 rękopisy: Sermones Jakuba de Voragine i Brewiarz. Taką samą ich liczbę odnotował inwentarz B. Były to: Incerti auctoris Liber Seneki oraz czwarta księga Sentencji Piotra Lombarda ${ }^{43}$.

\footnotetext{
${ }^{35}$ Tamże, s. 237-240; J. A. Kosiński, dz. cyt., s. 395-400.

${ }^{36}$ Sz. Starowolski, Arka Testamentu, Zamykająca $w$ sobie kazania niedzielne całego roku, ná dwie cześsi rozdzielone..., Kraków 1649 (K. Estreicher, Bibliografia polska, cz. 3: Obejmująca druki stuleci XV-XVIII w uktadzie abecadtowym (dalej: Estreicher, cz. 3), t. 18, Kraków 1933, s. 188).

${ }^{37}$ J. Liberiusz, Gospodyni Nieba i Ziemie, Naświętsza Panna Maryja dwudziesta kazań na Hymn kościelny O Gloriosa Domina etc. po różnych w Krakowie kościołach..., Kraków 1650 (Estreicher, cz. 3, t. 10, Kraków 1906, s. 260-261).

${ }^{38}$ Kazania S. Franciszka Salezyjusza biskupa i książęcia genewskiego na niektóre święta i niedziele, którym przydane sa także fragmenta niektórych kazań, i pieśni Salomonowych mistyczne objaśnienie niegdy przez Zakonnice Nawiedzenia Najświętszej MPanny wiernie zebrane w Annesium a teraz przez też Zakonnice Klasztoru Warszawskiego z francuskiego jezzyka na polski przettumaczone, Warszawa 1693 (Estreicher, cz. 3, t. 5, Kraków 1898, s. 283).

${ }^{39}$ Ludwik z Granady, Przewodnik grzeszników..., Lublin 1687 (Estreicher, cz. 3, t. 6, Kraków 1899, s. 331).

${ }^{40}$ Rok niebieski, albo przewodnik do szczęśliwej wieczności, Jezusowi Królowi niebieskiemu, Maryi Królowej niebieskiej, i wszystkim świętym mieszkańcom Niebieskim, na cześć i chwałę przez miesiące i dni roztożony, od jednego Kapłana Soc. Jesu roku, którego życie przedwieczne w ciele ludzkim dla nas żyć poczęto 1697, Kalisz 1697 (Estreicher, cz. 3, t. 12, Kraków 1910, s. 14).

${ }^{41}$ Reguta S. Augustyna Hippońskiego, biskupa i doktora kościelnego. Constitucie sióstr wtórego habitu zakonu kaznodziejów, przełożone na polskie przez F. N. M[ościckiego] ord. praed. z zlecenia przełożonych, [Warszawa 1695 — według katalogu księgarskiego] (Estreicher, cz. 3, t. 1, Kraków 1891, s. 295).

${ }^{42}$ APPDK. KDG.

${ }^{43}$ CPDCL, s. 69, 79; T. Stolarczyk, dz. cyt., s. 240.
} 
W łowickiej bibliotece dominikańskiej znajdowało się jedynie 6 książek w języku polskim: Postilla Polonica Marcina Białobrzeskiego ${ }^{44}, 3$ egzemplarze Mesyjasza Stanisława Karnkowskiego ${ }^{45}$ i Eucharystia ${ }^{46}$ tegoż autora oraz Postillae (Kazania) Piotra Skargi (tytuł nieustalony). Pozostałe dzieła, a zatem zdecydowana większość, zostały napisane w języku łacińskim. Według inwentarza A w łowickim księgozbiorze znajdował się tylko jeden rękopis: Rosarium sermonum Bernarda de Bustis, natomiast według inwentarza B było ich już 57: 14 kodeksów dzieł św. Augustyna, dziewięć kodeksów dzieł św. Tomasza z Akwinu, dziewięć kodeksów dzieł Roberta Bellarmina, sześć kodeksów dzieł Ludwika z Granady, cztery kodeksy Biblii, dwa kodeksy Concordantiae Sententiarum Piotra Lombarda, trzy kodeksy dzieł św. Antonina Pierozzi, dwa kodeksy Moraliów św. Grzegorza Wielkiego, jeden kodeks dzieł Laktancjusza, dwa kodeksy Ecclesiasticae historiae Nicefora Callistusa z Konstantynopola, dwa kodeksy Historiae ecclesiasticae Euzebiusza z Cezarei, jeden kodeks De divinis Apostolicis Ecclesiasticis Traditionibus Martina Pereza de Ayala oraz trzy manuskrypty Sermonum nieznanego autora ${ }^{47}$.

W klasztorze piotrkowskich dominikanów znajdowały się tylko trzy książki w języku polskim. Były to dwa egzemplarze Biblii, O bóstwie Syna Bożego Jakuba Wujka ${ }^{48}$ oraz O lichwie i trzech przedniejszych kontraktach: wyderkowym, czynszowym, i Towarzystwa Kupieckiego, nauka krótka Marcina Śmigleckiego ${ }^{49}$. Inwentarz A wykazał tylko jeden rękopis: Liber scriptus Sermonum, natomiast inwentarz B dwa: Sermones manu scripti i Loci communes Sacrae Scripturae ${ }^{50}$.

W księgozbiorze sieradzkich Braci Kaznodziejów książek w języku polskim było 10: 4 egzemplarze dzieł Piotra Skargi ${ }^{51}$, bliżej nie określone wydania Biblii w 2 egzemplarzach, 1 egzemplarz Nowego Testamentu, Mesyjasz Karnkowskiego, Katechizm polski Walentego Kuczborskiego ${ }^{52}$, Księgi o gospodarstwie Pietro Crescenzi [Crescentyn

\footnotetext{
${ }^{44}$ Prawdopodobnie: M. Białobrzeski, Postilla orthodoxa..., Kraków 1581; tenże, Postille albo wykłady świętnych Ewanjelij..., Kraków 1581 (Estreicher, cz. 3, t. II, Kraków 1894, s. 6).

${ }^{45}$ St. Karnkowski, Mesyjasz albo kazania..., Poznań 1597 (Estreicher, cz. 3, t. 8, Kraków 1903, s. 120).

${ }^{46}$ Tenże, Eucharystia abo o Przenaświetszym Sakramencie i Ofierze ciała i krwie Pana Zbawiciela i Boga naszego, pod osobą chleba i wina, kazań czterdzieści..., Kraków 1602 (Estreicher, cz. 3, t. 8, Kraków 1903, s. 119).

${ }^{47}$ APPDK. CPDCLv, s. 26-31, 39-41; T. Stolarczyk, Biblioteka towickiego konwentu dominikańskiego w początkach XVII wieku i jej księgozbiór, „Fides. Biuletyn Bibliotek Kościelnych” 2010, nr 1-2 (30-31), s. 181.

${ }^{48}$ J. Wujek, O bóstwie Syna Bożego i Ducha Świętego..., Kraków 1590 (Estreicher, cz. 3, t. 22, Kraków 1939, s. 381-382).

${ }^{49}$ M. Śmiglecki, O lichwie i trzech przedniejszych kontraktach..., Wilno 1596 (Estreicher, cz. 3, t. 17, Kraków 1930, s. 308).

${ }^{50}$ APPDK. KKDPt.

${ }^{51}$ P. Skarga, Żywoty Świętych Starego i Nowego Zakonu na każdy dzień przez caly rok, wybrane, Kraków 1592; tenże, Żywoty Swiętych Starego i Nowego Zakonu na każdy dzień przez caly rok, wybrane [...]. Teraz znowu przez niegoż przegladane i czwarty raz $w$ druk podane, Kraków 1598; tenże, Kazania o siedmi sakramentach Kościoła S. katolickiego. Do których sa przydane Kazania przygodne, o rozmaitych nabożeństwach wedle czasu..., Kraków 1600; tenże, Kazania na niedziele i święta, całego roku..., wiele wydań (Estreicher, cz. 3, t. 17, Kraków 1930, s. 142-145, 147, 162-163).

52 W. Kucborski, Katechizm albo nauka wiary i pobożności krześcijańskiej, wedtug Concilium, przez uczone a bogobojne ludzie zebrana i spisana..., Kraków 1568 (Estreicher, cz. 3, t. 9, Kraków 1905, s. 358).
} 
polski o gospodarstwie $]^{53}$. Jeśli chodzi natomiast o manuskrypty w sieradzkiej bibliotece, to inwentarz A wykazuje 1: Historia antiquitatis per folia descripta, zaś inwentarz B 2: Lombardica Historia in pergameno i Liber quidam scriptus sine titulo. Rękopisami były jednak przede wszystkim księgi liturgiczne, w tym trzy psałterze: dwa pergaminowe i jeden papierowy, znajdujące się poza zasadniczą biblioteką ${ }^{54}$.

Biblioteki gidelskich, łęczyckich, łowickich, piotrkowskich i sieradzkich dominikanów były typowymi bibliotekami klasztornymi owego czasu: zdecydowanie przeważały dzieła teologiczne (w Łowiczu według inwentarza A 18 woluminów, a inwentarza B 41 woluminów), istniała duża liczba pism kaznodziejskich (w Sieradzu ok. 100 woluminów - inwentarz A 62 woluminy, inwentarz B 46 nowych egzemplarzy, w Gidlach 86, w Piotrkowie Trybunalskim 53 woluminy) i polemicznych (najwięcej w Sieradzu 50 woluminów). Brakowało literatury pięknej w języku polskim oraz dzieł z zakresu wiedzy przyrodniczej; autorzy kościelni, zwłaszcza dominikańscy (przede wszystkim św. Tomasz z Akwinu) i jezuiccy, dominowali nad autorami świeckimi. To co wyróżniało je in minus na tle innych bibliotek Braci Kaznodziejów w Polsce, to skromna liczba egzemplarzy Biblii, autorów starożytnych, filozofów antycznych, zwłaszcza tak ważnego dla tomizmu Arystotelesa, chociaż były komentarze do jego dzieł oraz z historii kościelnej i świeckiej. Znajdowały się za to pojedyncze dzieła Seneki, Boecjusza i Laktancjusza ${ }^{55}$.

Spośród osób, które najbardziej zasłużyły się dla organizacji opisanych bibliotek, należy wymienić Feliksa z Wierzbna herbu Gozdawa, żyjącego w XVI wieku dwukrotnego prowincjała polskiego i przeora krakowskiego. W drugiej połowie XVI wieku przekazał on klasztorowi w Sieradzu znaczny księgozbiór, dokładnie nie wiadomo jak duży, który stał się podstawą XVI- i XVII-wiecznej biblioteki konwentualnej $j^{56}$.

The Libraries of Preacher Brethren of Gidle, Łęczyca, Łowicz, Piotrków

Trybunalski and Sieradz and Their Book Collections in the 17th century:

A Comparative Analysis

\section{Summary}

The aim of the hereby article is to present the epitome of Dominican Convent libraries situated within the area of the former archdeaconry of Łęczyca: in Gidle, Łęczyca, Łowicz, Piotrków Trybunalski and Sieradz, as well as their book collection originating from XVII century. They were functioning since the monasteries were funded, the evidence of what is the existence of Dominican schools which could not do without libraries. Extra thought was given to the books at the Order of Preacher Brethren, which is expressed in its legislation. Disobedience to the library rules resulted in severe consequences including

\footnotetext{
${ }_{53}$ Ksiegi o gospodarstwie, i o opatrzeniu rozmnożenia rozlicznych pożytków, każdemu stanowi potrzebne, Kraków 1549 (Estreicher, cz. 3, t. 3, Kraków 1896, s. 450-451).

${ }^{54}$ APPDK. CPCS, s. 173-189, 223-229; J. A. Kosiński, dz. cyt., s. 400-401; Z. Łuczak, dz. cyt., s. 40.

55 APPDK. KDG; APPDK. CPDCLv, s. 26-31, 39-41; APPDK. KKDPt; APPDK. CPCS, s. 173-189, 223-229; CPDCL, s. 69-73, 78-80; J. A. Kosiński, dz. cyt., s. 401; R. Skrzyniarz, Zbiory kazań w polskich ksiegozbiorach okresu średniowiecza, ABMK: t. 70: 1998, s. 256; Z. Łuczak, dz. cyt., s. 39-41; T. Stolarczyk, Biblioteka tęczyckiego konwentu dominikańskiego, s. 241.
}

${ }^{56}$ J. A. Kosiński, dz. cyt., s. 393-394; Z. Łuczak, dz. cyt., s. 31-32. 
excommunication. The analysis of the mentioned book resources was carried out on the basis of Latin library inventories from the $17^{\text {th }}$ century, which were included in the codex of Preacher Brethren of Łęczyca, Łowicz and Piotrków and Gidle inventory created in the beginning of XX century. All those inventories are now stored in the archives of the Polish Province of Dominicans in Kraków. The largest book collection was in the possession of Sieradz Dominicans - about 400 volumes. The second largest collection was in Gidle library with 345 volumes. In third position was the library of Łowicz Convent which collection comprised 294 volumes. The fourth biggest library was the library in Piotrków which stored 215 volumes. In the Łęczyca library there were about 100 volumes in the beginning of XVII century. 